\title{
Potential intravenous drug interactions in intensive care*
}

\author{
Potenciais interações de medicamentos intravenosos em terapia intensiva \\ Potenciales interacciones de fármacos intravenosos en cuidados intensivos
}

\author{
Maiara Benevides Moreira' ${ }^{1}$, Maria Gefé da Rosa Mesquita², Marluci Andrade Conceição Stipp ${ }^{2}$, Graciele Oroski Paes ${ }^{3}$
}

How to cite this article:

Moreira MB, Mesquita MGR, Stipp MAC, Paes GO. Potential intravenous drug interactions in intensive care. Rev Esc Enferm USP. 2017;51:e03233. DOI: http://dx.doi.org/10.1590/S1980-220X2016034803233

\begin{abstract}
* Extracted from the final course work "Potenciais interações medicamentosas por via intravenosa: análise de prescrições em terapia intensiva”, Escola de Enfermagem Anna Nery, Universidade Federal do Rio de Janeiro, 2015.

${ }^{1}$ Universidade Federal do Rio de Janeiro, Escola de Enfermagem Anna Nery, Programa de Pós-Graduação em Enfermagem, Rio de Janeiro, RJ, Brazil.

${ }^{2}$ Universidade Federal do Rio de Janeiro, Escola de Enfermagem Anna Nery, Departamento de Metodologia da Enfermagem, Rio de Janeiro, RJ, Brazil.

${ }^{3}$ Universidade Federal do Rio de Janeiro, Escola de Enfermagem Anna Nery, Departamento de Enfermagem Fundamental, Rio de Janeiro, RJ, Brazil.
\end{abstract}

\begin{abstract}
Objective: To analyze potential intravenous drug interactions, and their level of severity associated with the administration of these drugs based on the prescriptions of an intensive care unit. Method: Quantitative study, with a retrospective exploratory design, and descriptive statistical analysis of the ICU prescriptions of a teaching hospital from March to June 2014. Results: The sample consisted of 319 prescriptions and subsamples of 50 prescriptions. The mean number of drugs per patient was 9.3 records, and a higher probability of drug interaction inherent to polypharmacy was evidenced. The study identified severe drug interactions, such as concomitant administration of Tramadol with selective serotonin reuptake inhibitor drugs (e.g., Metoclopramide and Fluconazole), increasing the risk of seizures due to their epileptogenic actions, as well as the simultaneous use of Ranitidine-Fentany ${ }^{\circledR}$, which can lead to respiratory depression. Conclusion: A previous mapping of prescriptions enables the characterization of the drug therapy, contributing to prevent potential drug interactions and their clinical consequences.
\end{abstract}

\section{DESCRIPTORS}

Drug Interactions; Patient Safety; Intensive Care Units; Critical Care Nursing; Infusions, Intravenous. 


\section{INTRODUCTION}

Drug interaction (DI) is characterized by a change in the action of a drug, caused by concomitant or previous administration of other medication(s). When drugs have a synergistic effect, the therapeutic effect may be potentiated; when antagonistic, concurrent administration may reduce their efficacy. In addition, drug interaction can interfere in the way drugs are absorbed, metabolized and/ or eliminated ${ }^{(1)}$.

The term "Theoretical Potential Drug Interactions" (TPDI) refers to the interactions already registered in the literature among the drugs present in the medical prescription, which may have occurred or not ${ }^{(2)}$.

Some drug interactions may be intentional; this interaction is treated as beneficial or desired. They may also be part of the patient's drug therapy, such as the concomitant administration of fentanyl and midazolam. This interaction is indicated to provide comfort and relief from anxiety in patients under mechanical ventilatory support, optimizing synchronization and oxygenation ${ }^{(3)}$. However, even a desired drug interaction requires observation and monitoring of clinical effects.

To date, there is no consensus in the literature regarding the correct terminology for drug interaction because, in addition to the term "adverse event", some authors treat DI as a medication error in the phase of medication prescription, or as a failure in monitoring a drug therapy ${ }^{(4)}$.

The main risk factors that contribute to the occurrence of these unwanted drug interactions are classified into: patient-related, drug-related, and prescription-related factors. Risk factors associated with patients are: age, concomitant pathology, and polypharmacy; with drugs, potential enzyme inhibitors or inducers, therapeutic margin and dose; and finally, the medical prescription-related factors, which refer to the high number of prescribed drugs, associated with the complexity of the clinical condition and intra- and extra-hospital prescriptions ${ }^{(4)}$.

The complexity of this care can be observed in the intensive care unit (ICU), where the treatment of hospitalized patients usually requires the prescription of multiple medications, which directly increases the probability of one or more drug interactions ${ }^{(2)}$. The results of the Harvard Medical Practice Study II indicate a $44.3 \%$ to $95 \%$ occurrence of potential drug interactions ${ }^{(5)}$. Thus, it is important to highlight the relevance of studying potential drug interactions in the ICU.

It is worth noting that the risk of drug-drug interaction increases with the number of drugs prescribed, in which the frequency of drug interaction may exceed $80 \%$ in prescriptions presenting polypharmacy ${ }^{(6)}$. Therefore, it is important to know this field well to characterize the most commonly used drug therapy, and thus to know the most likely interactions.

In the drug therapy system, prescription is crucial for patient safety, and deserves extreme attention in the preparation, so that the chance of error is the smallest possible. A study by the American Medical Association revealed that $56 \%$ of medication errors occur in the prescription phase $\mathrm{e}^{(7)}$.
Therefore, prescription is the first barrier in order to hinder the occurrence of drug interaction.

Medical status, complexity, and polypharmacy are very important elements involving DI. In addition, the drug's route of administration is paramount because it can determine the speed and severity of the drug interaction ${ }^{(2)}$. In this study, we approached the drugs administered intravenously; it is noted that, because administration is made directly into the circulation, very rapid adverse responses can often occur.

Based on the above, the following research questions were created: Which are the most important drug classes? What are the potential drug interactions and degrees of severity?

Aiming to contribute to the knowledge about potential drug interactions in the ICU and, as a consequence, also contribute to the nursing and multidisciplinary team practice, the objective of the present study was to analyze potential drug interactions, and the respective degrees of severity of intravenous medications from the medical prescriptions in an intensive care unit.

\section{METHOD}

This is a quantitative approach study, using the exploratory retrospective design, mediated by documentary analysis of the drug prescriptions of the intensive care unit of a teaching hospital in Rio de Janeiro. This is a public reference hospital, part of the Sentinel Network, considered a center of excellence in teaching, research and extension. The ICU of this hospital is divided into surgical and clinical areas, each with six beds, and the former has greater patient turnover.

Data collection took place between July and August 2014, in the medical records of patients hospitalized from June 2013 to June 2014. For sample calculations, the number of patients admitted in this period was surveyed, being a population of 485 admissions. Considering a sample error of $5 \%$ and a $95 \%$ confidence interval, the calculated sample was 110 records. For prescription stratification, the days of patient hospitalization in the period were counted; totaling 7,920 prescriptions. With a sample error of $5 \%$ and 95\% confidence interval being calculated, a sample of 319 prescriptions was obtained.

Inclusion criteria were: prescriptions of patients hospitalized from June 2013 to June 2014; prescriptions with the physician register number, and drugs administered intravenously. Exclusion criteria were: illegible handwritten prescriptions, and medical records with no ICU prescriptions. The selection of medical records to obtain prescriptions was randomized from the list of patients hospitalized in the facility, with one out of five patients being chosen.

Prescriptions were then selected from these and, in each medical record, at least one, and at most five prescriptions were analyzed. To do so, the authors established the maximum number of prescriptions to ensure the presence of at least one different drug in each prescription, thus avoiding repeated drug mapping.

Data extracted from the prescriptions were: gender, age, drug name, and intravenous drug pharmaceutical form. The database was built using the software Excel ${ }^{\circledR} 2007$, and the data were submitted to a descriptive statistical analysis. In 
order to answer the research questions, the sample of 110 medical records and 319 prescriptions was considered for the drug characterization and subsequent grouping according to drug class.

Of the total number of medical records, 50 were randomly extracted in order to better refine the treatment of TPDIs, based on the Micromedex ${ }^{\circledR}$ Healthcare Series system, a support tool containing reliable databases, with information based on systematic reviews of drugs, toxicology and other previous mapping of prescriptions, which provides the characterization of drug therapy of notorious worldwide knowledge ${ }^{(8)}$.

The limitations of the research were due to the fact that some prescriptions were incompletely filled in because they were related to unstable patients, who often require the addition of medications. It is also considered that drug scheduling must be analyzed in future studies.

The present study is part of the integrated research project entitled: Boas Práticas Aplicadas à Segurança do Paciente: estudo sobre administração medicamentosa (Good Practices Applied to Patient Safety: a study on drug administration), approved by the institution's Research Ethics Committees under Report no. 336.436, of August 1, 2013/CAAE 17589513.0.0000.5238. Because this is a study with human beings, it is in compliance with Resolution No. 466/2012 of the National Health Council.

\section{RESULTS}

The sample represents approximately $23 \%$ of the population that went through the ICU during the research period. It is a heterogeneous group, with several reasons for ICU admission, such as acute and postoperative cases of high complexity, with patients aged between 20 and 86 years. A total of 140 drugs with different dosages, 33 drug classes, and a mean of 9.3 drugs per prescription were prescribed, with a standard deviation of \pm 5.3 .

The drugs found in the prescriptions were grouped into 33 drug classes, and the classes with the greatest relevance at the ICU were: electrolyte replacement (25.19\%), antibiotics (10.61\%), anti-peptic ulcer (10.09\%), antipyretics (8.41\%) and antiemetics (8.37\%), as illustrated in Figure 1, which shows the percentage of drugs per drug class.

In the 50 medical records, with one prescription each, the number of drugs per patient and their singularities could be observed. Figure 2 shows the number of drugs per patient, with a maximum of 23 , and a minimum of 1 drug.

Chart 1 shows the number of prescriptions per drug, which were divided into 3 groups (A, B and C) according to the frequency in prescriptions. Group $\mathrm{C}$ is the most prominent, because it consists of drugs prescribed more than ten times. The most frequent drugs in this group were: Dipyrone (44 prescriptions), Saline Solution 0.9\% (36 prescriptions), Ringer Lactate (24 prescriptions), Omeprazole (23 prescriptions) and Bromopride (20 prescriptions).

The search for theoretical potential drug interactions in the prescriptions was made based on the Micromedex ${ }^{\circledR}$ system, using the Drug Interactions tool, which shows the incompatibility of each drug. In addition, this tool classifies interactions as to their degree of severity into: contraindicated, when concomitant use is not indicated; severe, when it presents a risk of death and/or requires an intervention to minimize serious adverse effects; moderate, when the DI may result in an exacerbation of the patient's clinical condition; or mild, when DI has a limited clinical effect ${ }^{(8)}$. The following illustration shows several potential drug interactions among the drugs of group $\mathrm{B}$, group $\mathrm{C}$ and between groups $\mathrm{B}$ and $\mathrm{C}$ (Figure 3).

$\%$ OF DRUGS PER CLASS

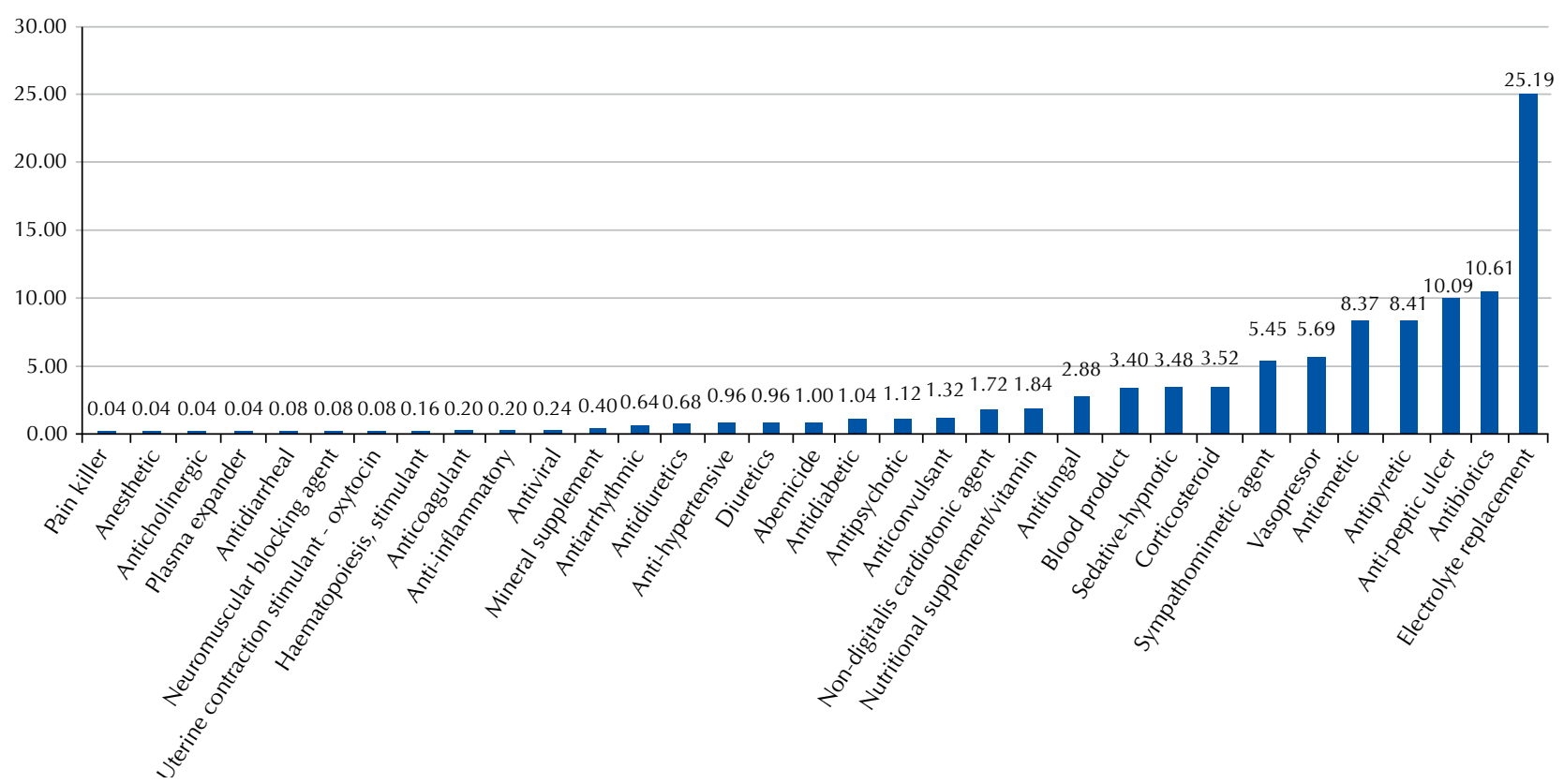

Figure 1 - Number of drugs per drug class sorted by frequency - Teaching Hospital, Rio de Janeiro, Rio de Janeiro, Brazil, 2014. Source: Created by the research authors. 
Box plot (N ${ }^{\circ}$ OF DRUGS PER PATIENT)
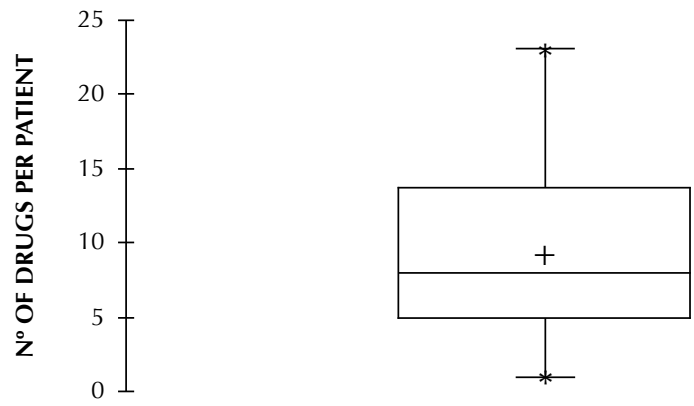

+ Mean * Min/Max

Figure 2 - Number of drugs per patient - Teaching Hospital, Rio de Janeiro, Rio de Janeiro, Brazil, 2014.

Source: Created by the research authors.

Chart 1 - Number of prescriptions per drug - Teaching Hospital, Rio de Janeiro, Rio de Janeiro, Brazil, 2014.

\begin{tabular}{|c|c|c|c|}
\hline DRUG & No. OF PRESCRIPTIONS & $\begin{array}{l}\text { DIVISION IN GROUPS ACCORDING TO THE } \\
\text { FREQUENCY OF PRESCRIPTIONS }\end{array}$ & $\begin{array}{l}\text { FREQUENCY OF } \\
\text { PRESCRIPTIONS }\end{array}$ \\
\hline Cefepime & $\mathbf{0}$ & \multirow{32}{*}{ GROUP A } & \multirow{32}{*}{$<5$ PRESCRIPTIONS } \\
\hline Sodium nitroprusside & $\mathbf{0}$ & & \\
\hline Azithromycin & $\mathbf{0}$ & & \\
\hline Nitroglycerine & $\mathbf{0}$ & & \\
\hline Tenoxicam & $\mathbf{0}$ & & \\
\hline Heparin & $\mathbf{0}$ & & \\
\hline Oxytocin & $\mathbf{0}$ & & \\
\hline Chlorpromazine & $\mathbf{0}$ & & \\
\hline Metoprolol & $\mathbf{0}$ & & \\
\hline Succinylcholine & $\mathbf{0}$ & & \\
\hline Gentamycin & $\mathbf{0}$ & & \\
\hline Adenosine & $\mathbf{0}$ & & \\
\hline Etomidate & $\mathbf{0}$ & & \\
\hline Atracurium & $\mathbf{0}$ & & \\
\hline Phenytoin & 1 & & \\
\hline Diazepam & 1 & & \\
\hline $\begin{array}{l}\text { Sulfamethoxazole }+ \\
\text { Trimethoprim }\end{array}$ & 1 & & \\
\hline Folic acid & 1 & & \\
\hline B Complex & 1 & & \\
\hline Ascorbic acid (Vit. B) & 1 & & \\
\hline Moxifloxacin & 1 & & \\
\hline Streptomycin & 1 & & \\
\hline Dopamine & 1 & & \\
\hline Zofran ${ }^{\circledR}$ & 1 & & \\
\hline Imipenem + Sodium cilastatin & 1 & & \\
\hline Clarithromycin & 1 & & \\
\hline Ampicillin & 1 & & \\
\hline Filgrastim & 1 & & \\
\hline Teicoplanin & 1 & & \\
\hline Phytomenadione (vit. K) & 1 & & \\
\hline Dexamethasone & 1 & & \\
\hline Micafungin & 1 & & \\
\hline
\end{tabular}

continued.. 
...continuation

\begin{tabular}{|c|c|c|c|}
\hline DRUG & No. OF PRESCRIPTIONS & $\begin{array}{l}\text { DIVISION IN GROUPS ACCORDING TO THE } \\
\text { FREQUENCY OF PRESCRIPTIONS }\end{array}$ & $\begin{array}{l}\text { FREQUENCY OF } \\
\text { PRESCRIPTIONS }\end{array}$ \\
\hline Clindamycin & 1 & \multirow{25}{*}{ GROUP A } & \multirow{25}{*}{ < 5 PRESCRIPTIONS } \\
\hline Hydroxyethylamide & 1 & & \\
\hline Pancuronium & 1 & & \\
\hline Atropine & 1 & & \\
\hline Ganciclovir & 1 & & \\
\hline Amoxicillin + Sulbactam & 2 & & \\
\hline Total Parenteral Nutrition (TPN) & 2 & & \\
\hline Cefazolin & 2 & & \\
\hline Amiodarone & 2 & & \\
\hline Polymyxin b & 2 & & \\
\hline Calcium gluconate & 2 & & \\
\hline Adrenaline & 2 & & \\
\hline Dobutamine & 3 & & \\
\hline Haloperidol & 3 & & \\
\hline Metronidazole & 3 & & \\
\hline Simple Ringer & 3 & & \\
\hline Morphine & 3 & & \\
\hline $\begin{array}{c}\text { Amphotericin b liposomal } \\
\text { complex }\end{array}$ & 3 & & \\
\hline Acyclovir & 3 & & \\
\hline Amikacin & 3 & & \\
\hline Hypertonic glucose $\mathbf{5 0} \%$ & 4 & & \\
\hline Potassium phosphate & 4 & & \\
\hline Ceftriaxone & 4 & & \\
\hline Sodium chloride $20 \%$ & 4 & & \\
\hline Methylprednisolone & 4 & & \\
\hline Glucose solution $10 \%$ & 5 & \multirow{15}{*}{ GROUP B } & \multirow{15}{*}{$\begin{array}{l}\text { FROM } 5 \text { TO } 10 \\
\text { PRESCRIPTIONS }\end{array}$} \\
\hline Piperacillin + Tazobactam & 5 & & \\
\hline Ondansetron & 5 & & \\
\hline Platelet concentrate & 5 & & \\
\hline Tramadol & 6 & & \\
\hline Human albumin & 6 & & \\
\hline Fluconazole & 6 & & \\
\hline Vancomycin & 6 & & \\
\hline Regular purified mixed insulin & 6 & & \\
\hline Vasopressin & 6 & & \\
\hline Fresh Plasma & 6 & & \\
\hline Packed red blood cells & 7 & & \\
\hline Potassium chloride $10 \%$ & 8 & & \\
\hline Magnesium sulfate $10 \%$ & 8 & & \\
\hline Furosemide & 8 & & \\
\hline Sodium bicarbonate $8.4 \%$ & 11 & \multirow{7}{*}{ GROUP C } & \multirow{7}{*}{ > 10 PRESCRIPTIONS } \\
\hline Glucose solution $\mathbf{5 0} \%$ & 12 & & \\
\hline Meropenem & 12 & & \\
\hline Midazolam & 13 & & \\
\hline Ranitidine & 14 & & \\
\hline Fentanyl® & 14 & & \\
\hline Glucose solution $5 \%$ & 15 & & \\
\hline
\end{tabular}

continued.. 


\begin{tabular}{|c|c|c|c|}
\hline DRUG & No. OF PRESCRIPTIONS & $\begin{array}{l}\text { DIVISION IN GROUPS ACCORDING TO THE } \\
\text { FREQUENCY OF PRESCRIPTIONS }\end{array}$ & $\begin{array}{l}\text { FREQUENCY OF } \\
\text { PRESCRIPTIONS }\end{array}$ \\
\hline Hydrocortisone & 17 & \multirow{8}{*}{ GROUP C } & \multirow{8}{*}{ > 10 PRESCRIPTIONS } \\
\hline Noradrenaline & 18 & & \\
\hline Metoclopramide & 18 & & \\
\hline Bromopride & 20 & & \\
\hline Omeprazole & 23 & & \\
\hline Ringer lactate & 24 & & \\
\hline $\begin{array}{c}\text { Saline } \\
\text { solution } 0.9 \%\end{array}$ & 36 & & \\
\hline Dipyrone & 44 & & \\
\hline
\end{tabular}

Source: Created by the research authors.

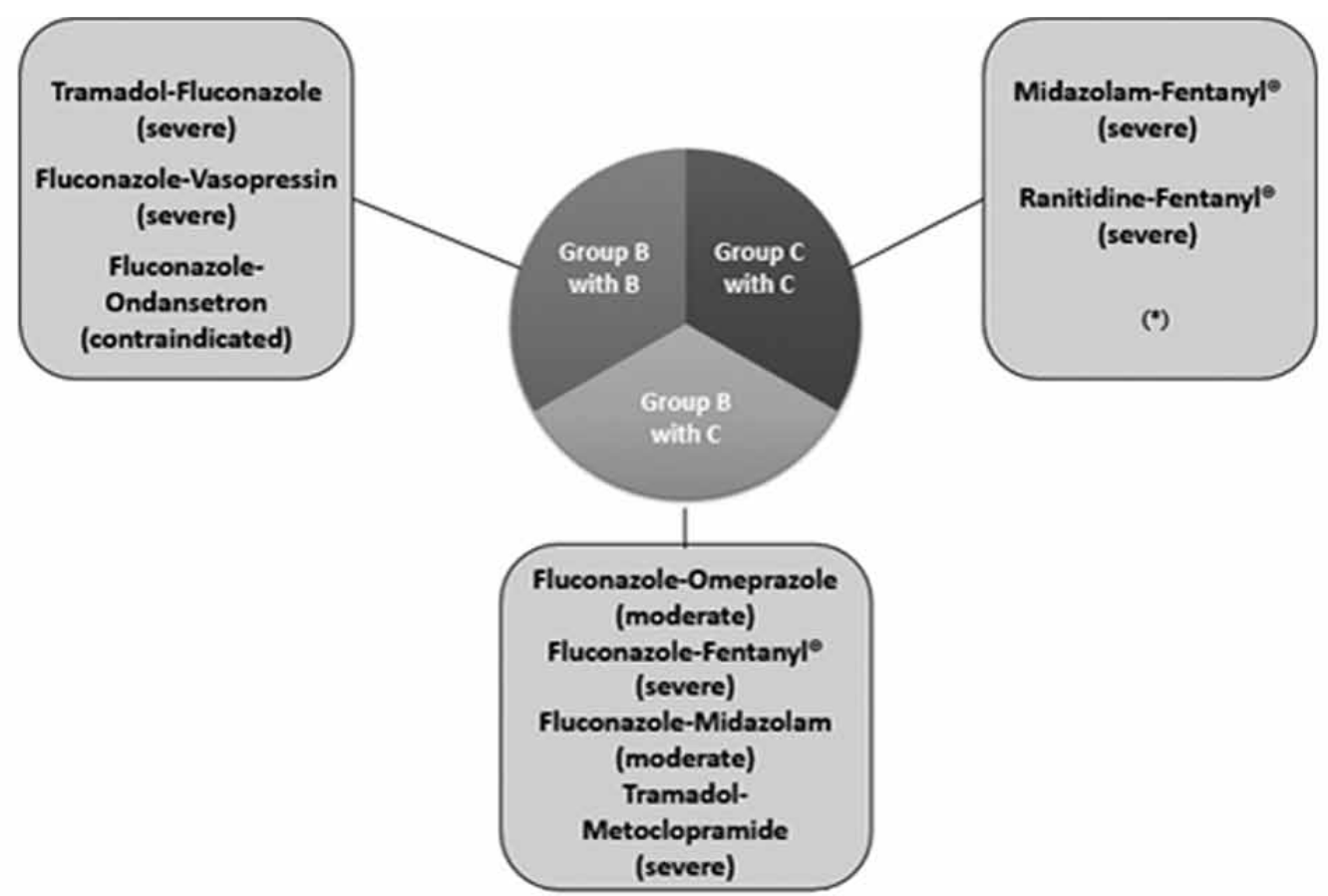

$\left.{ }^{*}\right)$ Omeprazole-Midazolam and Midazolam-Ranitidine are moderate drug interactions but were not found in the Micromedex ${ }^{\circledast}$ Healthcare Series.

Figure 3 - Theoretical potential drug interactions in the most relevant groups - Teaching Hospital, Rio de Janeiro, Rio de Janeiro, Brazil, 2014.

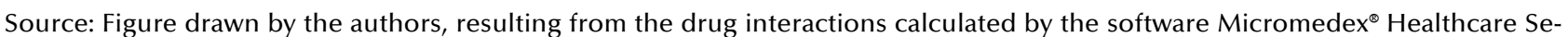
ries, $2011^{(8)}$.

\section{DISCUSSION}

The results of this study contribute to the evaluation of potential drug interactions in the ICU prescriptions. It is known that in intensive care the probability of a DI is high due to the environment's high complexity, and prescriptions with many medications ${ }^{(2)}$, which is called polypharmacy. These prescriptions are one of the main risk factors for the occurrence of drug interactions and adverse drug reactions, which are directly proportional to the increase in the number of drugs prescribed ${ }^{(1,9-10)}$. Therefore, it is worth noting that the result of the mean number of drugs per patient of 9.3 is quite relevant and it presents a high probability of occurrence of drug interaction. Importantly, the risk of interactions raise to virtually $100 \%$ with eight or more medications prescribed ${ }^{(9)}$.
The mean age of the patients was 58.2 years with a standard deviation of \pm 17.07 , which usually occurs in the intensive care setting. Taking older age, physiological changes, and clinical condition's severity into account, potential drug interactions are important in this sector, even mild DIs, because they may have undesirable consequences, such as worsening of the clinical condition, increasing hospital length of stay ${ }^{(5)}$.

Ninety-six types of medications were found in ICU prescriptions. The knowledge about the drugs used and their potential drug interactions is extremely important, because they may occur more frequently, since a great variety of therapy increases the risk of DI considerably ${ }^{(2-5)}$.

This knowledge should not be exclusive to a professional of the health team, but available to all professionals, favoring patient safety, and serving as clinical support for decision 
making, which avoids more severe decompensations ${ }^{(3)}$. The responsibility of the nursing staff within the multiprofessional team is great. Regarding drug safety, nurses play an important role, as they are present during several stages of the drug process; thus, this professional can prevent drug interaction, for example, by identifying a potential interaction in the prescription ${ }^{(11)}$.

The most relevant classes of ICU prescriptions are usually associated with clinical and surgical characteristics of hospitalized patients ${ }^{(2)}$, such as the need for electrolyte replacement, pain relief, the inherent risk of infection, and the prevention of peptic ulcers. Although this is described in the literature, it was not evidenced in the present study, as shown in Figure 1, where electrolytic replacements appear 629 times, analgesics 358 , antibiotics 265 , and anti-peptic ulcers 252 times, as the most relevant drug classes.

Analgesics are characteristic of patients admitted to the ICU, since most of the time they undergo painful procedures, and receive this medication class to provide relief and comfort $^{(1)}$. Another example is antibiotics, which are highly prescribed because of the high rates of infection in ICU, five to ten times higher than in other hospital units ${ }^{(12)}$.

Figure 2 shows that the maximum number of drugs prescribed per patient is 23 , and the minimum is $1 \mathrm{drug}$, configuring an amplitude of 22 drugs, which constitutes a particularity in the scenario investigated, both of clinical patients, who are in most cases critical patients, and surgical patients, who most of the time need less medications.

Chart 1 shows that groups $\mathrm{B}$ and $\mathrm{C}$ are the most relevant. Thus, it is important to call attention to the drugs that make up these groups, because their potential drug interactions may not always be serious, but are very likely to occur.

Following the analysis by the Micromedex ${ }^{\circledR}$ Healthcare Series software, based on the drugs mapped, potential drug interactions classified as serious were identified, such as: Tramadol-Fluconazole, Fluconazole-Fentany ${ }^{\circledR}$, Fluconazole-Vasopressin, Midazolam-Fentanyl ${ }^{\circledR}$, Ranitidine-Fentanyl ${ }^{\circledR}$; and Tramadol-Metoclopramide. Therefore, the nurses' knowledge about the drugs that will be administered is extremely important for the prevention of DI, because knowing potential drug interactions makes the professional able to identify them early, allowing for rapid intervention, since serious interactions are classified this way because they can lead to death.

The concomitant administration of Tramadol and selective serotonin reuptake inhibitor drugs, such as Metoclopramide and Fluconazole, increases the risk of seizures, because these agents are often individually epileptogenic, and may have additive effects when combined ${ }^{(13)}$. Fluconazole-Fentanyl ${ }^{\circledR}$ interaction increases or prolongs the sedative effects of Fentanyl ${ }^{\circledR}$ because Fluconazole inhibits the cytochrome P450-3A4 enzyme complex (CYP4503A4), which is responsible for the biotransformation of Fentany $1^{\circledR}$, increasing serum levels of Fentany ${ }^{\circledR}$, leading to an exacerbation of its sedation effect, increasing the risk of hypersedation ${ }^{(14)}$.
The main consequence of concomitant administration of Midazolam-Fentanyl ${ }^{\circledR}$ is respiratory depression, but concomitant use of these drugs is commonly used based on pharmacological synergism, where they are used to provide comfort and relief of anxiety in patients on mechanical ventilation $^{(15)}$. Ranitidine is an inhibitor of the enzyme system of opioids, which promotes an increase in the bioavailability and toxicity of opioids. Thus, the concurrent use of Ranitidine with Fentanyl ${ }^{\circledR}$ may lead to respiratory depression ${ }^{(9)}$.

With all of these potential drug interactions raised in the present study, it is of paramount importance that the entire health team pays attention to drug prescriptions, so that early identification of TPDI takes place. Otherwise, the team should monitor the possible consequences, intervene and discuss suspension of the combination or dose adjustment ${ }^{(5)}$.

All health professionals should work together to form a multi-barrier and avoid unplanned DIs. This should take place as of the prescribing process (medical professional), through the scheduling of administration (nurses) and management (pharmacist and nursing staff), up to medication administration (nursing team).

So that not only the drug process, but the entire patient care process is safe, communication among health care professionals should be effective. Studies recommend communication as a daily competence in nursing care, both the communication among the multiprofessional team and communication between the nurse and the individual receiving care, which conveys safety and comfort to the latter. Lack of communication or ineffective communication keeps the staff apart from patients and family members, and has a direct impact on the quality of care provided ${ }^{(16)}$.

\section{CONCLUSION}

The present study reiterates that polypharmacy, a daily situation in intensive care units, directly increases the risk of drug interaction. Attention to patients with a high number of drugs prescribed should be doubled. This makes the knowledge by all health professionals about each patient's drug therapy of paramount importance for DI to be mitigated. The multiprofessional team should always be attentive to all phases of the drug process, from the prescription by the medical professional to the administration of the drug by the nursing team, acting as multi-barrier so that DI do not happen, or are early identified.

It should be noted that a previous mapping of prescriptions allows the characterization of drug therapies, which contributes to prevent potential drug interactions, minimizing the risk of harm to the patient's clinical condition.

Nurses in particular should treat each prescription in a special way, considering the clinical and drug singularity of each patient, exercising their autonomy in the schedule of drug administration and also, if necessary, suggesting the substitution of medications. Therefore, as one of the main health assistants, nurses play a fundamental role in the prevention of drug interactions and their possible clinical consequences. 
com análise estatística descritiva das prescrições medicamentosas do Centro de Terapia Intensiva de um Hospital Universitário no período de março-junho/2014. Resultados: A amostra foi composta de 319 prescrições e subamostras de 50 prescrições. Constatouse que a média de medicamentos por paciente foi de 9,3 registros, e evidenciou-se maior probabilidade para ocorrência de interação medicamentosa inerente à polifarmácia. O estudo identificou interações medicamentosas graves, como a administração concomitante de Tramadol com medicamentos inibidores seletivos da recaptação da serotonina, (exemplo: Metoclopramida e Fluconazol), aumentando o risco de convulsões devido às suas ações epileptogênicas, além do uso simultâneo de Ranitidina-Fentanil ${ }^{\circledR}$, que pode ocasionar depressão respiratória. Conclusão: $\mathrm{O}$ mapeamento prévio das prescrições possibilita a caracterização da terapêutica medicamentosa, contribuindo para obstar as potenciais interações medicamentosas e suas consequências clínicas.

\section{DESCRITORES}

Interações de Medicamentos; Segurança do Paciente; Unidades de Terapia Intensiva; Enfermagem de Cuidados Críticos; Infusões Intravenosas.

\section{RESUMEN}

Objetivo: Analizar las potenciales interacciones medicamentosas intravenosas y su grado de severidad asociadas con la administración de esos fármacos mediante las prescripciones del Centro de Cuidados Intensivos. Método: Estudio cuantitativo, tipología retrospectiva exploratoria, con análisis estadístico descriptivo de las prescripciones medicamentosas del Centro de Cuidados Intensivos de un Hospital Universitario en el período de marzo-junio/2014. Resultados: La muestra estuvo compuesta de 319 prescripciones y submuestras de 50 prescripciones. Se constató que el promedio de fármacos por paciente fue de 9,3 registros y se evidenció mayor probabilidad para ocurrencia de interacción medicamentosa inherente a la polifarmacia. El estudio identificó interacciones medicamentosas severas, como la administración concomitante de Tramadol con fármacos inhibidores selectivos de la recaptación de serotonina (por ejemplo: Metoclopramida y Fluconazol), aumentando el riesgo de convulsiones en virtud de sus acciones epileptogénicas, además del empleo simultáneo de Ranitidina-Fentanil ${ }^{\circledR}$, lo que puede ocasionar depresión respiratoria. Conclusión: El mapeo previo de las prescripciones posibilita la caracterización de la terapéutica medicamentosa, contribuyendo a impedir las potenciales interacciones medicamentosas y sus consecuencias clínicas.

\section{DESCRIPTORES}

Interacciones de Drogas; Seguridad del Paciente; Unidades de Cuidados Intensivos; Enfermería de Cuidados Críticos; Infusiones Intravenosas.

\section{REFERENCES}

1. Cedraz KN, Santos Junior MC. Identificação e caracterização de interações medicamentosas em prescrições médicas da unidade de terapia intensiva de um hospital público da cidade de Feira de Santana, BA. Rev Soc Bras Clin Med. 2014;12(2):124-30.

2. Mazzola PG, Rodrigues AT, Cruz AA, Marialva M, Granja S, Battaglini SCM, et al. Perfil e manejo de interações medicamentosas potenciais teóricas em prescrições de UTI. Rev Bras Farm Hosp Serv Saúde. 2011;2(2):15-9.

3. Vieira LB, Reis A, Lima RE, Faria LM, Cassiani SHB. Interações medicamentosas potenciais em pacientes de Unidades de Terapia Intensiva. Rev Ciênc Farm Básica Apl. 2012;33(3):401-8.

4. Cassiani SHB. Hospitais e medicamentos: impacto na segurança dos pacientes. São Caetano do Sul (SP): Yendis; 2010. p. 35-44.

5. Silva LD, Matos GC, Barreto BG, Albuquerque DC. Drug scheduling for nurses in prescriptions at sentinel hospital. Texto Contexto Enferm. 2013;22(3):722-30.

6. Leão DFL, Moura CS, Medeiros DS. Avaliação de interações medicamentosas potenciais em prescrições da atenção primária de Vitória da Conquista (BA), Brasil. Ciênc Saúde Coletiva. 2014;19(1):311-8.

7. Wachter RM. Compreendendo a segurança do paciente. $2^{a}$ ed. Porto Alegre: AMGH; 2013.

8. Micromedex $®$ Healthcare Series [Internet database] Greenwood Village: Thomson Reuters (Healthcare); 2011

9. Melgaço TB, Carrera JS, Nascimento DEB, Maia CSF. Polifarmácia e ocorrências de possíveis interações medicamentosas. Rev Paraense Med [Internet]. 2011 [citado 2016];25(1). Available from: http://files.bvs.br/upload/S/0101-5907/2011/v25n1/a2585.pdf

10. Moura CS, Prado N, Acurcio FA. Potential drug-drug interactions associated with prolonged stays in the intensive care unit a retrospective cohort study. Clin Drug Investig. 2011;31(5):309-16.

11. Camerini FG, Silva LD, Mira AJM. Nursing actions for a safe medications administration: an integrative review. J Res Fundam Care Online. 2014;6(4):1655-65

12. Cardinal LSM, Matos VTG, Resende GMS, Toffoli-Kadri MC. Characterization of drug prescriptions in an adult intensive care unit. Rev Bras Ter Intensiva. 2012;24(2):151-6.

13. Okuno MFP, Cintra RS, Vancini-Campanharo CR, Batista REA. Drug interaction in the emergency service. Einstein. 2013;11(4):462-6.

14. Carvalho REFL, Reis AMM, Faria LMP, Zago KSA, Cassiani SHB. Prevalence of drug interactions in intensive care units in Brazil. Acta Paul Enferm. 2013;26(2):150-7.

15. Faria LMP, Cassiani SHB. Medication interaction: knowledge of nurses in intensive care units. Acta Paul Enferm. 2011;24(2):264-70.

16. Pott FS, Stahlhoefer T, Felix JVC, Meier MJ. Medidas de conforto e comunicação nas ações de cuidado de enfermagem ao paciente crítico. Rev Bras Enferm. 2013;66(2):174-9. 